\title{
Pembuatan Jelly Menggunakan Daun Kacapiring (Gardenia Augusta Merr.) untuk Menambah Variasi Kuliner kota Balikpapan
}

\author{
Farida $^{1^{*}, \text { Chandra Irawan }^{2}, \text { Hilmansyah }}{ }^{3}$ \\ 1,2,3 Jurusan Perhotelan, Politeknik Negeri Balikpapan, Balikpapan \\ *farida@poltekba.ac.id
}

\begin{abstract}
Gardenia Plants is a similar plant to jasmine flowers with another name of gardenia jasminoides which means flowers and similar to jasmine flowers that have a very fragrant distinctive aroma. This research is aimed 1) to find out whether processed of leaves kacapiring can be used as the main ingredient of jelly making, 2) to tell the extent of the favorite and the quality of jelly, leaves kacapiring in terms of color, aroma, texture, and think, 3) for the jelly leaves kacapiring with jelly leaves cincau. This type of research used is experimental research, organoleptic test, and the comparison. The data collected from the organoleptic test to be analyzed statistically descriptive using the program of SPSS 20, 0 for Windows. The leaves of kacapiring can be processed into jelly, but not with the quality of the jelly, 2) based on the results of the hedonik, an average 3,55 of the panelists said like in terms of color, aroma, texture, and taste, 3) based on the results of the quality of hedonik get results in terms of color an average of jelly kacapiring 4, 48, very green, the smell of 3,96 a little smell, texture, stood a little chewy, and the jelly kacapiring 3,96 is bitter, 4) based on the results, the authors concluded that the cincau jelly leaves has better quality than kacapiring jelly leaves
\end{abstract}

Keyword:plants gardenia, jelly, organoleptik.test

\begin{abstract}
Abstrak
Bunga kacapiring merupakan tanaman mirip bunga melati dengan nama lain Gardenia Jasminoides yang artinya bunga mirip dengan bunga melati mempunyai aroma khas sangat harum.Penelitian ini bertujuan untuk 1) untuk mengetahui apakah olahan sari daun Kacapiring dapat dijadikan bahan utama pembuatan jelly, 2) untuk mengetahui tingkat kesukaan dan mutu jelly sari daun Kacapiring dari segi warna, aroma, tekstur, dan rasa, 3) untuk mengetahui perbandingan jelly daun Kacapiring dengan jelly daun cincau.Jenis penelitian yang digunakan yaitu penelitian eksperimen, uji organoleptik, dan uji perbandingan. Data yang terkumpul dari uji organoleptik akan dianalisis secara statistik deskriptif menggunakan program SPSS 20,0For Windows. Berdasarkan penelitian yang telah dilakukan: 1) didapatkan hasil bahwa sari daun Kacapiring dapat diolah menjadi jelly namun tidak dengan kualitas jelly yang baik, 2) berdasarkan hasil uji hedonik didapatkan rata-rata 3,55 yaitu panelis menyatakan suka dari segi warna, aroma, tekstur, dan rasa, 3) berdasarkan hasil uji mutu hedonik didapatkan hasil dari segi warna rata-rata jelly Kacapiring 4,48 sangat hijau, aroma3,96 agak harum, tekstur3,04 agak kenyal, dan rasa jelly Kacapiring 3,96 pahit, 4) berdasarkan dari hasil analisis penulis menyimpulkan bahwa jelly daun cincau ternyata memiliki kualitas lebih baik dibandingkan dengan jelly daun Kacapiring.
\end{abstract}

Kata kunci: tanaman kacapiring, jelly, uji organoleptik

\section{Pendahuluan}

Indonesia kaya akan keanekaragaman

hayati sebagian digunakan sebagai bahan

pangan yang dapat dikonsumsi sehari-hari, dan sebagian juga dapat dijadikan sebagai bahan obat-obatan tradisional, namun tidak sedikit juga tanaman dapat dijadikan sebagai 
obat sekaligus dapat juga dikonsumsi menjadi suatu panganan yang enak dan menyehatkan.

Salah satu tanaman yang dijadikan sebagai bahan obat-obatan dan dapat juga dijadikan sebagai panganan yang enak untuk dinikmati yaitu bunga Kacapiring atau (Gardenia August Merr).Kacapiring berasal dari Cina dan Jepang, bisa ditemukan sebagai tanaman hias di pekarangan pada daerah pegunungan dengan ketinggian $400 \mathrm{~m}$ dpl dan baru berbuah jika ketinggian sekitar 3000 kaki dpl.Perdu tegak dengan tinggi 1 - 2 meter ini mempunyai batang bulat berkayu, bercabang, ranting muda dan daunnya berlapis lilin.Daun letaknya berhadapan atau berkarang tiga, tebal dan licin seperti kulit, bertangkai pendek, bentuknya elips, warnanya hijau tua.Bunga tunggal, bertangkai pendek, warnanya putih, baunya harum (Dalimartha, 2003: 30).

Bunga kacapiring merupakan tanaman mirip bunga melati dengan nama lain Gardenia Jasminoides yang artinya bunga mirip dengan bunga melati mempunyai aroma khas sangat harum. Bunga kacapiring termasuk tumbuh-tumbuhan bergendre perdu dari suku kopi-kopian atau Rubiaceae. Bunganya berwarna putih dan sangat harum tanaman ini juga dikenal dengan nama biomial gardenia jasmoinedes berarti seperti melati (Thomas, 1992: 44)

Bunga kacapiring selama ini dikenal oleh masyarakat sebagai tanaman obat antibiotik, selain itu juga dapat mengobati hepatitis, sariawan, menurunkan demam. Identifikasi fitokimia daun Kacapiring menunjukkan bahwa daun Kacapiring mengandung senyawa flavonoid, saponin, polifenol, dan crocetin, crosin dan scandosida, dalam abu daun terdapat natrium, kalsium, kalium, magnesium, besi, tembaga dan timbal yang sangat berguna bagi kesehatan, dan dapat menyembuhkan berbagai macam penyakit seperti Diabetes Mellitus, penurunan demam, sariawan, sembelit dan gangguan air besar lainnya (Wijayakusuma, 2000).

Hal ini berarti sangat menguntungkan jika tanaman ini dapat diolah menjadi suatu panganan dengan memadukan antara tanaman herbal dengan sajian kuliner, akan memberikan variasi kuliner yang beraneka ragam. Pembuatan bahan pangan dari sari daun yang berbahan dasar daun Kacapiring segar ini dapat menjadikan daun Kacapiring sebagai bahan pangan fungsional. Menurut Haryono (2003), bahwa pada prinsipnya makanan fungsional merupakan makanan yang dirancang secara khusus dengan memanfaatkan senyawa bioaktif yang mempunyai peran dalam mencegah penyakit.

Semakin maraknya restoran siap saji yang menyajikan aneka makanan dan minuman di kota Balikpapan berupa makanan dan minuman disajikan secara moderen dan berkelas sehingga sangat berpengaruh pada 
gaya hidup masyarakat yang cenderung memilih makanan dan minuman yang praktis. Namun dipandang dari segi kesehatan kurang baik dikonsumsi secara terus menerus karena akan sehingga makanan tradisional menjadi pilihan kedua. Salah satu panganan tradisional adalah cincau suatu panganan yang berbentuk jelly dan merupakan campuran minuman yang menyegarkan. Jelly merupakan makanan yang banyak disukai segala usia, mulai dari orang dewasa, remaja dan anak-anak. Namun panganan ini sudah jarang disajikan di restoran, cafe atau bahkan di warung-warung, masyarakat lebih cenderung memilih makanan dan minuman instan selain rasa yang enak, juga dengan harga yang murah. Namun ditinjau dari segi kesehatan tidak terlalu menguntungkan.

Untuk itu diperlukan inovasi baru untuk menambah variasi kuliner khususnya di kota Balikpapan. Dengan memberikan variasi baru bagi pencinta kuliner nusantara dengan menggunakan potensi lokal yaitu dengan memanfaatkan tanaman hias sebagai bahan alternative pada pembuatan jelly, sehingga menambah variasi kuliner tidak hanya mengenal cincau sebagai sajian minumanyang menyegar namun jelly dari bunga kacapiring akan menambah perbendaharaan kuliner yang ada di kota Balikpapan. Daun Kacapiring (Gardenia August Merr) yang diekstrak dengan air dapat membentuk gel atau jelly.
Sifat fungsional daun Kacapiring yang diekstrak dengan air, mempunyai kemampuan membentuk jelly karena merupakan hidrokoloid alami daun yang mengandung sebagian besar air dengan sifat khas padat, khususnya sifat elastis dan kekauan (Fardiaz, 1989).

Gel atau jelly dimanfaatkan sebagai salah satu sumber pangan yang mengandung komponen bioaktif seperti klorofil dan total fenol yang dijadikan sebagai sumber antioksidan alami sehingga menghasilkan panganan enak dan menyehatkan kemudian disajikan dan dikemas sesuai dengan perkembangan jaman diharapkan akan menjadi salah satu panganan yang disukai dan dirindukan oleh pencinta kuliner di kota Balikpapan.

\section{Metoda Penelitian}

Penelitian ini merupakan penelitian eksperimen. Penelitian eksperimen adalah penelitian yang dilakukan dengan mengadakan manipulasi terhadap objek penelitian serta diadakan kontrol terhadap variabel tertentu (Hasan, 2002).Selanjutnya akan dilakukan uji organoleptik untuk mengetahui tingkat kesukaan (hedonik) dan mutu hedonik. Pengujian organoleptik disebut penilaian indera atau penilaian sensorik merupakan suatu cara penilaian dengan memanfaatkan panca indera manusia untuk mengamati 
tekstur, warna, bentuk, aroma, rasa suatu produk makanan, minuman ataupun obat (Ayustaningwarno, 2014). Dalam penelitian ini terdapat dua tahap penelitian, yaitu tahap pertama penelitian pendahuluan dan tahap kedua penelitian lanjutan.

\subsection{Tahap Penelitian}

Penelitian pendahuluan dilakukan untuk menguji resep acuan cing cau hijau sebanyak 50 lembar daun cingcau dan $500 \mathrm{ml}$ air.

Penelitian lanjutan digunakan untuk mengetahui tingkat kesukaan dan mutu hedonik konsumen/panelis terhadap produk jelly daun kacapiring.

\section{A. Uji hedonik}

Uji kesukaan juga disebut uji hedonik. Dalam uji hedonik, panelis diminta tanggapan pribadinya tentang kesukaan atau sebaliknya ketidaksukaan, disamping panelis mengemukakan tanggapan senang, suka atau sebaliknya. Tingkat-tingkat kesukaan ini disebut skala hedonik.Skala hedonik dapat direntangkan atau diciutkan menurut rentangan skala yang dikehendaki. Misalnya "suka" dalam skala hedonik seperti: sangat suka, suka, agak suka, tidak suka.

Dalam penelitian yang dilakukan yaitu uji organoleptik terhadap terhadap pembuatan jelly daun kacapiring dilihat dari aspek tekstur, warna, aroma, tekstur, dan rasa.

B. Uji Mutu Hedonik
Berbeda dengan uji kesukaan, uji mutu hedonik tidak menyatakan suka atau tidak suka, melainkan menyatakan kesan tentang baik atau buruk.Kesan baik-buruk ini disebut kesan mutu hedonik.Kesan mutu hedonik lebih spesifik daripada sekedar kesan suka atau tidak suka.Rentangan skala hedonik berkisar dari ekstrim baik sampai ke ekstrim jelek.

Uji mutu hedonik bertujuan untuk mengetahui respon panelis terhadap sifat mutu yang umum dimana panelis akan menjawab instrumen dengan bobot nilai yang telah ditentukan. Untuk kategori warna, aroma, tekstur dan rasa. Untuk kategori warna nilai 5 sangat hijau, nilai 4 hijau, nilai 3 agak hijau, nilai 2 kurang hijau, nilai 1 tidak hijau. kategori aroma nilai 5 sangat beraroma kacapiring, nilai 4 beraroma kacapiring, nilai 3 agak beraroma kacapiring, nilai 2 agak beraroma kacapiring, nilai 1 tidak beraroma kacapiring. Kategori tekstur nilai 5 sangat kenyal, nilai 4 kenyal, nilai 3 agak kenyal, nilai 2 tidak kenyal, nilai 1 sangat tidak kenyal. kategori rasa nilai 5 sangat pahit, nilai 4 pahit, nilai 3 agak pahit, nilai 2 tidak pahit, nilai 1 sangat tidak pahit.

\subsection{Prosedur Penelitian}

Penelitian dimulai mencari referensi resepacuan hingga pengujian hasil produk yang dihasilkan. Adapun prosedur penelitian yang digunakan dalam penelitian ini sebagai berikut: 
1. Bahan yang digunakan dalam penelitian.

a. Daun bunga kacapiring yang merupakan bahan utama pembuatan jelly.

b. Air merupakan bahan untuk ekstraksi daun kacapiring yang kemudian menghasilkan sari.

\section{Peralatan yang digunakan dalam penelitian}
a. Baskom (Bowl)
b. Pisau (Knife)
c. Talenan (Cutting board)
d. Timbangan (Scale)
e. Gelas Ukur (Measuring jug)
f. Saringan (Strainer)
g. Sendok (Spoon)
h. Catakan plastik (Plastic mold)

\section{Hasil Penelitian}

Penelitian telah dilakukan dengan 2 tahapan yaitu, tahapan pendahuluan yaitu pada tahapan ini peneliti melakukan uji resep acuan cincau hijau. Selanjutnya dari resep acuan tersebut dilakukan eksperimen untuk mendapatkan jelly dengan menggunakan daun kacapiring, yang selanjutnya akan dilakukan uji organoleptik untuk mengetahui tingkat kesukaan dan kelayakan jelly daun kacapiring. Penelitian lanjutan menggunakan panelis agak terlatih sebanyak 25 panelis. Panelis agak terlatih yaitu panel yang berada antara panelis terlatih dan panelis tidak terlatih, panelis dalam kategori ini mengetahui sifat-sifat

sensorik dari sampel yang diuji karena memahami tentang produk yang akan diuji. Kelompok yang termasuk dalam kategori ini antara lain mahasiswa semester 6 (enam) jurusan tata boga politeknik negeri Balikpapan.

Tabel 1. Hasil Uji Hedonik dan MutuHedonik

\begin{tabular}{clrrrr}
\hline No & Uraian & Warna & Aroma & Tekstur & Rasa \\
\hline 1 & Hedonik & 3,80 & 3,84 & 3,36 & 3,20 \\
\hline 2 & $\begin{array}{l}\text { Mutu } \\
\text { Hedonik }\end{array}$ & 4,48 & 3,96 & 3,04 & 3,96 \\
\hline
\end{tabular}

Berdasarkanhasil uji hedonik yang meliputi warna, aroma, tekstur, dan rasa diperoleh hasil sebagai berikut:

\section{A. Warna}

Berdasarkan nilai rata-rata pada warna jelly daun Kacapiring didapatkan nilai 3,80, hal ini menunjukkan bahwa rata-rata panelis menyatakan suka pada warna daun Kacapiring berdasarkan total keseluruhannya.

B. Aroma

Berdasarkan nilai rata-rata pada aroma Kacapiring didapatkan nilai 3,84, hal ini dapat menunjukkan bahwa dari segi aroma panelis banyak yang suka aroma dari jelly daun Kacapiring.

C. Tekstur 
Berdasarkan nilai rata-rata pada tekstur Kacapiring didapatkan nilai 3,32, hal ini dapat menunjukkan bahwa dari segi tekstur panelis banyak yang suka tekstur dari jelly daun Kacapiring.

D. Rasa

Berdasarkan nilai rata-rata pada rasa Kacapiring didapatkan nilai 3,32, hal ini dapat menunjukkan bahwa panelis banyak yang agak suka rasa dari jelly daun Kacapiring.

Berdasarkan hasil uji mutu hedonik yang meliputi, warna, aroma, tekstur dan rasa diperoleh hasil sebagai berikut:

\section{A. Uji Mutu Hedonik Warna}

Berdasarkan nilai rata-rata pada warna jelly daun Kacapiring didapatkan nilai 4,48 yaitu dengan banyaknya panelis yang menyatakan jelly daun kacapiring berwarna sangat hijau.

\section{B. Uji Mutu Hedonik Aroma}

Berdasarkan nilai rata-rata pada aroma jelly Kacapiring didapatkan nilai 3,96 yaitu dengan banyaknya panelis menyatakan aroma jelly daun Kacapiringagak harum.

\section{Uji Mutu Hedonik Tekstur}

Berdasarkan nilai rata-rata pada tekstur Kacapiring didapatkan nilai 3,04 yaitu dengan banyaknya panelis menyatakan tekstur jelly daun Kacapiringagak kenyal.

\section{Uji Mutu Hedonik Rasa}

Berdasarkan nilai rata-rata pada rasa jelly Kacapiring didapatkan nilai 3,04, yaitu dengan banyaknya panelis yang menyatakan rasa pahit pada jelly daun Kacapiring.

Berdasarkan hasil perbandingan pembuatan jelly daun cincau hijau dengan hasil pembuatan jelly daun Kacapiring bahwa jelly daun cincau ternyata memiliki kualitas lebih baik dibandingkan dengan jelly daun Kacapiring, karena tekstur yang didapat dari jelly daun Kacapiring kurang kenyal, warna terlalu hijau pekat dan rasa pahit. Sedangkan jelly daun cincau memiliki tekstur yang kenyal, warna tidak hijau pekat dan rasa tidak pahit. Dengan menggunakan 50 lembar daun cincau, dapat menghasilkan jelly dengan kualitas yang baik, sedangkan 50 lembar (25gr) daun Kacapiring belum bisa menghasilkan jelly. Hali ini dikarenakan konsentrasihidrokoloid daun cincau sekitar 5\% sehingga sangat berpengaruh pada kekentalan larutannya, menghasilkan buih yang lebih banyak sehingga mempengaruhi fisik serta mempercepat terjadinya sinersis, jell cincau lebih kuat karena memiliki karakter sifat fisik yang jauh lebih baik dan memiliki umur simpan yang lama $\left(5^{\circ} \mathrm{C}\right)$ selama 30 hari penyimpanan dibandingkan disimpan pada suhu ruang.

sedangkan kandungan hidrokoloid pada daun kacapiring mempunyai konsentari rendah kurang dari 5\% sehingga kandungan gel yang diperoleh bersifat lebih encer dan tidak dapat 
bertahan lama, yaitu hanya dapat bertahan sampai 1 hari pada suhu $5-10^{\circ} \mathrm{C}$

\section{Kesimpulan}

Berdasarkan penelitian yang telah dilakukan dengan mempertimbangkan uji hedonik dan mutu hehonik yang meliputi aspek warna, aroma, tekstur, dan rasa, didapatkan bahwa sari daun Kacapiring dapat diolah menjadi jelly.

Tahap awal proses pembuatan jelly sari daun Kacapiring adalah proses pemetikan daun, penimbangan daun, pencucian daun, peremasan daun yang dicampur dengan air hangat kuku, kemudian yang terakhir adalah pencetakan.

Berdasarkan uji hedonik jelly sari daun Kacapiring didapatkan hasil bahwa dari segi warna rata-rata jelly Kacapiring 3,80, aroma 3,84, tekstur 3,36, dan rasa jelly Kacapiring 3,20, dari total keseluruhan uji hedonik didapatkan rata-rata 3,55 yaitu panelis menyatakan suka terhadap jelly daun Kacapiring dari segi warna, aroma, tekstur, dan rasa.

Berdasarkan uji mutu hedonik jelly sari daun Kacapiring didapatkan hasil dari segi warna rata-rata jelly Kacapiring 4,48 sangat hijau, aroma3,96 agak harum, tekstur3,04 agak kenyal, dan rasa jelly Kacapiring 3,96 pahit.

Berdasarkan dari hasil analisis yang telah dilakukan bahwa jelly daun cincau ternyata memiliki kualitas lebih baik dibandingkan dengan jelly daun Kacapiring, karena tekstur yang didapat dari jelly daun Kacapiring kurang kenyal, warna terlalu hijau pekat dan rasa pahit. Sedangkan jelly daun cincau memiliki tekstur yang kenyal, warna tidak hijau pekat dan rasa tidak pahit, hal ini disebabkan karena kandungan hidrokoloid alami yang terkandung dalam daun Kacapiring kurang dari 5\% sedangkan kandungan hidrokoloid pada cincau dengan konsentrasi 5\% sehingga menghasilkan jelly yang berkualitas baik.

\section{Saran}

Berdasarkan hasil penelitian ini telah dilakukan banyak kekurangan oleh karena itu peneliti menyarankan beberapa hal untuk mengembangkan penelitian ini kedepannya. Hal tersebut adalah:

a. Diharapkan adanya penelitian lebih luas untuk mengetahui masa simpan jelly daun Kacapiring.

b. Diharapkan untuk meneliti lebih dalam tentang kandungan hidrokoid yang terkandung pada daun kacapiring.

c. Perlunya membudidayakan tanaman bunga Kacapiring sehingga lebih memudahkan dalam membuat produk yang lebih besar 


\section{Daftar Pustaka}

Ayuningwarno F. (2014) Teknologi Pangan Teori Praktis dan Aplikasi. Yogyakarta. Graha Ilmu.

Dalimartha S. (2003). "Atlas Tumbuhan Obat Indonesia Jilid 3".Cetakan I.Puspa Swara. Jakarta

Fardiaz D. (1989). "Hidrokoloid.Laboratorium Kimia dan Biokimia Pangan".Pusat Antar Universitas Pangan dan Gizi, Institut Pertanian Bogor.

Haryono. (2003). "Prosedur Analisis untuk Bahan Makanan dan Pertanian". Liberty :Yogyakarta.

Hasan, M.Ikbal. (2002). Metodologi Penelitian dan Aplikasinya. Jakarta: Ghalia Indonesia.

Thomas,A.N.S. (1992). "Tanaman Obat Tradisional 2".Kanisius:Yogyakarta

Wijayakusuma,H. (2000). "Tumbuhan Berkhasiat Obat Indonesia", Jilid I, Hal : 71-75, Prestasi Gema Insani, Jakarta. 